\title{
Students Perceptions on Effectiveness of Guidance Programmes in Enhancing Study Skills in Secondary Schools in Bungoma North Subcounty, Kenya
}

\author{
Wanjala Soita John* Catherine Mumiukha \\ Department of Psychology, Counselling and Educational Foundations, Egerton University
}

\begin{abstract}
Examination preparedness is essential in helping students do well in examinations. As a result many schools have put in place guidance programmes to equip students with examination preparedness skills. This study sought to establish the perceptions of students on the effectiveness of guidance programmes in enhancing student examination preparedness in secondary schools in Bungoma North Sub-county, Kenya. The study was guided by the social cognitive theory and the interference theory. The descriptive survey research design was used in this study. The target population was all students in secondary schools in Bungoma North Sub County. The accessible population was 2938 Form 4 students from 32 public secondary schools. Stratified sampling was used to select 9 secondary schools. Nassiuma's formula and stratified and simple random sampling was used to obtain 186 student respondents. Students' questionnaire was used to collect data. The validity of the research instruments was ensured by generating the quesionnaire items in line with the research objectives. The instrument was piloted using 30 Form 4 students from secondary schools in Bungoma South Subcounty who did not participate in the actual study. Data was analysed using descriptive statistics which included mean, standard deviation, frequencies and percentages with the aid of the Statistical Package for Social Sciences version 22. The study concluded that guidance programme was effective in enhancing study skills among students in secondary schools in Bungoma North Sub County. Hence, students perceived guidance programme as being helpful in enhancing study skills.
\end{abstract}

Keywords: Guidance programme, Exam preparedness, Perception, Study Skills

DOI: $10.7176 / \mathrm{JEP} / 10-8-03$

Publication date:March $31^{\text {st }} 2019$

\section{Introduction}

The genesis of guidance is traced in Europe and the United States of America in the 1900s (Makinde, 1984). The focus of guidance by then was to provide vocational information. By 1950s, there was an increase in youth challenges which necessitated expansion of guidance programmes. Taylor (2012) observes that in reaction to the increased youth challenges in the society, family and schools, guidance programmes were introduced in British schools. According to Harris (2013) guidance in British schools was meant to support academically underachieving students, reduce student dropout rates, prepare students for the world of work and life and create a safe school environment (Lonborg \& Bowen, 2012). In Australia, guidance programmes were introduced to help students living in distressed families and those facing academic challenges.

However, inadequate financial and human resources and lack of knowledge on the part of the implementers of guidance programmes have been reported as barriers to the implementation of guidance programmes in schools in South Africa (Mahlangu, 2011; Chivonivoni, 2006; Chireshe, 2006). In Malawi, Maluwa (2012) established that guidance programmes have helped students to better understand their own academic interests, abilities and potentials. In Tanzania guidance programmes are regarded as being redundant and lacking trained personnel to make them effective (Biswalo, 1996). Similar findings have been reported in studies done in Botswana and Zambia. In Botswana, guidance programmes have been perceived as being meant for individuals infected or affected by HIV/AIDS (Sima, 2004).

\section{Guidance and Counselling Programmes in Kenya}

In Kenya, guidance and counseling was introduced in 1967 during the first guidance and career conference held to discuss career choices among students (Kilonzo, 2015; Oketch \& Ngumba, 2009). In the succeeding years, guidance and counseling was strengthened and emphasized by Education Commissions. The Report of the Task Force on Student Discipline and Unrest in Secondary Schools recommended that the Ministry of Education should appoint teacher counsellors for every public school to offer guidance programmes. Currently the guidance programme is increasingly being recognized as a necessary programme to enable students cope with the current rapid economic, social, political, occupational, technological and cultural changes in the modern world. The aim of guidance in schools is to equip students with the competencies needed to optimize their academic and personal potentialities.

Some studies have assessed the perception of students on effectiveness of guidance programmes in secondary schools (Owino, 2005; Mutie \& Ndambuki, 2003; Kariuki, 2010). According to Sweetnam (2012) guidance 
programmes contribute to improved study skills among students. Effective study skills eliminate test anxiety and increase confidence, hence improving performance. According to Owino (2005) and Nwachukwa (2007) school guidance can improve students' examination preparedness if students have a positive perception of the programmes. Guidance programmes that focus on examination preparedness can lessen anxiety which is associated with poor performance in examinations. Hence, guidance programmes have become more critical in enhancing preparedness for the Kenya Certificate of Secondary Education examinations.

In the Kenya Certificate of Secondary Education results of 2014, it was highlighted that some candidates simply wrote their names on the scripts and submitted them for marking (King'ori, 2015). Consequently, out of the 446,697 KCSE candidates in 2013,31.6\% of the total candidature scored grade D and below. According to Wango (2007) there is need for intervention through guidance programmes to improve on performance in the national examination. Students can be guided to adopt effective study skills. In Bungoma North Sub County, secondary schools have significantly stagnated in KCSE examination results as presentd in Table 1.

\section{Table 1}

KCSE Results Analysis-Bungoma North Sub County (2010-2016)

\begin{tabular}{cccccccccccccccc}
\hline Year & Entry & & \multicolumn{1}{c}{ Grade } & \multicolumn{1}{c}{ C- } & B & B & B- & C & C & C- & D + & D & D- & E & Mean \\
\hline 2010 & 1769 & 0 & 10 & 26 & 39 & 71 & 136 & 207 & 319 & 399 & 371 & 171 & 16 & 4.60 \\
2011 & 2110 & 2 & 10 & 39 & 66 & 112 & 183 & 315 & 384 & 431 & 380 & 211 & 11 & 4.83 \\
2012 & 2362 & 0 & 14 & 36 & 75 & 115 & 176 & 281 & 394 & 474 & 483 & 263 & 23 & 4.66 \\
2013 & 2372 & 1 & 5 & 36 & 80 & 112 & 172 & 264 & 399 & 560 & 490 & 214 & 14 & 4.36 \\
2014 & 2582 & 0 & 9 & 56 & 112 & 182 & 254 & 424458 & 464501 & 447 & 454 & 174 & 14111 & 4.66 \\
2015 & 2923 & 0 & 3 & 27 & 108 & 226 & 343 & 208 & 456 & 474 & 485 & 470967 & 184 & 4.56 \\
2016 & 3509 & 0 & 5 & 14 & 39 & 61 & 105 & & & 661 & 825 & & & 3.35
\end{tabular}

(Source: Bungoma North Sub County Education Office, 2016)

This means that a majority of students have been scoring grades lower than the recommended mean of C. Though it is argued that quality education is not merely passing examinations, performance grades are the most widely used indicators of education quality. Psacharopaulos and Woodhall (2010) observe that students' academic performance is a key indicator of education output. Like in other sub counties, guidance programme is being embraced to assist students to handle day to day social, personal, study tasks arising from their involvement in school activities. However, its effectiveness in enhancing students study skills depends on how students perceive the programme. This study sought to determine the perceptions of students on the effectiveness of guidance programme in enhancing study skills in secondary schools in Bungoma North Sub County.

\section{Methodology}

The study was based on the descriptive survey research design. The design allowed the researcher to describe the state of affairs of the variables being examined as they exist. It also allowed the researcher to collect data from the respondents about their perceptions on the effectiveness of guidance programmes in enhancing study skills. The target population was all students from public secondary schools in Bungoma North Sub County. The accessible population for the study was 2938 Form Four students and teacher counsllors from 32 public secondary schools in Bungoma North Sub County. Stratified sampling was used to categorize the schools into zones. Using simple random sampling, three schools were selected from each zone. Stein's method (Nassiuma, 2000) was used in selecting 186 study respondents. Simple random sampling was then applied to select the number of students to participate in the study from each school. Data was collected using self generated questionnaires for students. validity of the instrument was ensured by generating the questionnaire items in line with the research objectives. The data was organized, coded, edited and analysed using descriptive statistics with the aid of SPSS latest version. Frequencies and percentages were used to analyse data.

\section{Results and Discussion}

\subsection{Students' Perceptions on Effectiveness of Guidance Programme in Enhancing Study Skills}

The study sought to ascertain the students' perceptions on the effectiveness of guidance programme in enhancing study skills. This was done by presenting the respondents with statements related to perceptions about the effectiveness of the guidance programme in enhancing study skills. The findings are presented in table 2. 
Table 2

Perceptions on Effectiveness of Guidance Programme in Enhancing Study Skills

\begin{tabular}{|c|c|c|c|}
\hline Statement & $\mathbf{N}$ & Mean & SD \\
\hline $\begin{array}{l}\text { My performance in exams is improved by the study skills I get from guidance } \\
\text { programme }\end{array}$ & 186 & 4.13 & 1.72 \\
\hline Guidance programme equips me with effective study skills & 186 & 3.13 & 1.55 \\
\hline Having effective study skills improves my attitude towards examinations & 186 & 3.84 & 1.48 \\
\hline During guidance programme I am taught how to become an effective time manager & 186 & 2.64 & 1.14 \\
\hline Tips on how to overcome procrastination are taught during guidance sessions & 186 & 4.03 & 1.56 \\
\hline Guidance programme helps me to learn how to avoid distractors when studying & 186 & 3.23 & 1.74 \\
\hline $\begin{array}{l}\text { I have improved my attitude towards all subjects due to guidance programme in our } \\
\text { school }\end{array}$ & 186 & 3.10 & 1.49 \\
\hline $\begin{array}{l}\text { I have learnt how to study in a condusive environment from guidance programme in } \\
\text { our school }\end{array}$ & 186 & 3.17 & 1.53 \\
\hline Guidance programme enables me to appreciate the benefits of studying in a group & 186 & 3.93 & 1.15 \\
\hline Guidance programme makes me identify effective study hours & 186 & 2.87 & 0.78 \\
\hline $\begin{array}{l}\text { Guidance programmes have made me prepare effectively using my personal study time } \\
\text { table }\end{array}$ & 186 & 2.98 & 1.08 \\
\hline $\begin{array}{l}\text { Through guidance programme I have learnt the importance of following my personal } \\
\text { study time table }\end{array}$ & 186 & 3.88 & 0.89 \\
\hline Guidance programme enables me to revise effectively & 186 & 3.35 & 1.06 \\
\hline Guidance programme equips me with skills on how to balance leisure and studying & 186 & 3.41 & 1.22 \\
\hline I have been encouraged to consult teachers by guidance programme & 186 & 4.08 & 1.05 \\
\hline
\end{tabular}

The results in table 2 show a positive perception by students towards guidance programme as revealed by higher response rate in regard to whether students' performance in exams had improved as a result of guidance on study skills, whether the students were encouraged during guidance programme to consult teachers and whether students were taught during guidance sessions tips on how to overcome procrastination as revealed by means responses of 4.13, 4.08 and 4.03 with a standard deviation of 1.72, 1.05 and 1.56 respectively. These results are also supported by previous studies which have shown that poor academic performance could be remedied by a comprehensive guidance programme. The motive for providing guidance to students is based on the fact that the more knowledge students have about subject contents, the more they will think about, understand and remember it.

These findings also agree with Lambert and Barley (2011) who reported that students' level of motivation for academic excellence can influence how effective guidance programme would be. Napier (2011) observes that leaving students on their own to develop self reliance, self understanding, self direction and problem solving skills without proper guidance may not yield lasting results. Ndirangu (2007) also observes that student perceptions towards guidance programme may be positive if it helps them to overcome procrastiation, poor study methods and reading techniques which are associated with poor performance. The findings concur with O’Dunoghue (2006) who observed that guidance programmes which emphasize effective study skills necessary to help students make most efficient use of time, learning resources and academic potential are likely to improve examination performance. This also agrees with Wanjama, Muraya and Gichaka (2006) who noted that guidance programmes can help students eliminate time wastage by making realistic revision schedule that makes sure that all sections of the syllabus are completed while also balancing work with leisure. Mwichabe (2010) confirms that guidance can help students come up with workable timetables that can be reviewed when deemed necessary especially to match with the examination preparedness.

From table 2 it is also evident that there was relatively high response rate in regard to whether guidance programme enabled students to appreciate the benefits of studying in a group, whether guidance programme helped students to learn the importance of following personal study time table and whether effective study skills improved their attitude towards examinations as reflected by a mean of 3.93, 3.88 and 3.84 with a standard deviation of 1.15 , 0.89 and 1.48 respectively. These results are also supported by previous studies which revealed that test anxious students were often deficient in academic skills, less prepared for the examination, lacked knowledge on appropriate study strategies and methods and the ability to manage time and other resources to meet the demands of academic tasks. The findings are also supported by Cook and Koffenberger (2003) who reported that study skills programme and individualized tutoring positively improved students performance. This also concurs with Wanjama, Muraya and Gichaka (2006) who noted that guidance programmes can help students eliminate time wastage by making realistic revision schedule that makes sure that all sections of the syllabus are completed while also balancing work with fun activities.

These findings are supported by Buzzan (2007) who argues that students need to be guided on how to effectively manage their time, become clear about what should be achieved in a given timeframe while prioritizing 
revision tasks within the given timeframe. This agrees with Payne and Whitaker (2006) who contend that lack of prioritizing time is failure to concentrate on important tasks with a temptation to spent much time on trivialities. Mwichabe (2010) confirms that it is impossible to manage time without a timetable. The findings show moderate moderate response rate in regard to whether guidance programme equipped the respondents with skills on how to balance leisure and studying, whether guidance programme enabled students to revise effectively and whether guidance programme helped the students to learn how to avoid distractors when studying as revealed by a mean of $3.41,3.35$ and 3.23 with a standard deviation of $1.22,1.06$ and 1.74. Also shown in table 2, there was a relatively low response rate in regard to whether guidance helped students to learn how to study in a condusive environment, whether guidance programme equiped students with effective study skills and whether the respondents had improved their attitude towards all subjects due to guidance programme as revealed by means of $3.17,3.13$ and 3.10 with a standard deviation of $1.53,1.55$ and 1.49 respectively.

However, there was a low response rate in regard to whether guidance programme helped students prepare effectively using their personal study time table, whether guidance programme made the respondents identify effective study hours and whether during guidance programme the respondents were taught how to become effective time managers as reflected by a mean of 2.98, 2.87 and 2.64 with a standard deviation of $1.08,0.78$ and 1.14 respectively. Napier (2011) observes that leaving students on their own to develop self reliance, self understanding, self direction and problem solving skills without proper guidance may not yield lasting results. Ndirangu (2007) also observes that student perceptions towards guidance programme may be positive if it helps them to overcome anxiety, poor self concept, poor methods of study, poor reading techniques, organ disabilities, indiscipline and poor concentration which are associated with poor performance.

\subsection{Gender Differences in Perceptions of the Effectiveness of Guidance Programme in Enhancing Students study skills}

The study compared gender differences in the perceptions of the effectiveness of guidance programme in enhancing students' study skills. Table 3 presents the mean comparisons of the gender differences.

Table 3:

Differences in Perception of the Effectiveness of Guidance Programme in Enhancing students'study skills

\begin{tabular}{llccc}
\hline Statements & Gender & N & Mean & SD \\
Effectiveness of guidance programme in enhancing students' & Boys & 70 & 3.639 & 0.354 \\
study skills & Girls & 116 & 3.782 & 0.307 \\
\hline
\end{tabular}

The results in table 3 show that some mean difference existed between girls (3.782) boys (3.639) on the perception of the effectiveness of guidance programme in enhancing students' study skills. This shows that guidance programme was perceived to be more effective in enhancing study skills among girls than boys. This concurs with Alexitch and Page (1997) who established that in Canada girls were more responsive to guidance and counselling services than boys. Moreover, Bruce and Cockreham (2004) found that in America guidance programme enabled girls to be more tolerant towards rules, more willing to make exceptions and more easily reconciled than boys while Singh (2014) established that in India guidance programme was significantly effective in enabling girls adjust to the school emotional environment than boys.

\section{Conclusions}

The purpose of the study was to examine the perceptions of students on the effectiveness of guidance programme in enhancing study skills. Based on the findings, the study concluded that students perceived guidance programme to be effective in enhancing examination preparation among students in secondary schools in Bungoma North Sub County. Students perceived guidance programme as being helpful in enhancing students' study skills.

\section{Recommendations}

The study recommends that there is need of equipping school counselors with skills on how to handle different aspects of examination preparation such as study habits, goal setting, attitudes towards exams, time management, test taking skills, past papers, study time table and group discussion. There is also need for the guidance programme to embrace all the counselling needs of students to enable them be more effective and all round learners. Guidance and counselling department should be prioritized in all schools and given enough financial and moral back up to boast study skills among students.

\section{References}

Alexitch, L. \& Page, R. (1997). 'Evaluation of Academic and Career Counselling Information and its Relation to Students Education Orientation', Canadian Journal of Counselling, 31 (3), p. 205-218.

Biswalo, K. (1996), An introduction to Guidance and Counselling Diverse Africa Contexts. Dar es Salaam: Dar es salaam University Press.

Bruce, M. A. \& Cockreham, D. (2004), 'Enhancing Spiritual Development of Adolescent Girls', Professional 
School Counselling, 7(5), P. 334- 342.

Buzzan, K. (2007), Survey of study habits and attitudes manual. New York: The Psychological Corporation.

Chireshe, R. (2006), 'An Assessment of the Effectiveness of School Guidance and Counselling Programmes in Zimbabwean Secondary Schools' Unpublished MEd Thesis, UNISA.

Chivonivoni, T. (2006), 'The State of School Counselling in Chiredzi North Secondary Schools', Unpublished Counselling Dissertation, Harare: Zimbabwe Open University.

Cook, S. \& Koffenberger, F. (2003), 'Effective test taking: Skills-acquisition versus anxiety-reduction techniques'. Journal of Counseling and Clinical Psychology, 48, 431-439.

Harris, T. (2013), 'Effects of classroom guidance on student achievement' Elementary School Guidance and Counseling, 27, 163-171.

Kariuki, N. R. (2010), 'Perceptions of students on social, family, and economic factors contributing to poor academic performance among secondary school students in Makuyu Division of Muranga South DistrictKenya', Unpublished Master's Thesis, Egerton University, Kenya.

Kilonzo, G. K. (2015), Guidance and counselling in Kenya: Seminar paper, Nairobi: The Bureau of Educational Research, Kenyatta University, Kenya.

Lambert, M., \& Barley, D. (2011), 'Research Summary on the therapeutic examination anxiety and psychotherapy outcome psychotherapy', Journal of counseling and development, 38 (4), 357-361.

Lonborg, K., \& Bowen, U. (2012), 'The changing guidance program and the counselor' The Counselor in a Changing World, 139-148.

Mahlangu, V. (2011), 'Dilemma in School District in Managing Career Counselling in South Africa', Journal of Emerging Trends in Educational Research and Policy Studies, 2:239-245.

Makinde, O. (1984), Fundamentals of Guidance and Counselling. London: MacMillan.

Maluwa, D. W. (2012), 'School counsellors' perception of a Guidance and Counselling programme in Malawi's secondary schools'. British Journal of Guidance and Counselling, 26(2): 287-295.

Mutie, H., \& Ndambuki, W. (2003), The Philosophy behind Guidance and Counselling. Nairobi: Gupa Press.

Mwichabe, F. (2010), 'University Student's Problems, Awareness and Preferences of Counselling Resources and Attitudes towards Seeking Help: A Case Study of Kenyaata University'. Unpublished Master of Education Psychology Thesis, Kenyaatta University, Nairobi.

Napier, E. (2011), Guidance and counselling Practices and Results. New York: Harper.

Nassiuma, D. K. (2000), Survey Sampling: theory and methods. Nairobi: University of Nairobi Press.

Ndirangu, P. N. (2007), 'Influence of Guidance and Counselling programme on academic performance of selected public secondary school students: a case of Bahati division, Nakuru District'. Unpublished Master's Thesis, Egerton University, Kenya.

Nwachukwu, D. N. (2007), The Teacher Counselor for Today's School. Calabar: University of Calabar Press.

O’Donoughue, R. (2006), Guidance and Counselling, Galway: National University of Ireland.

Oketch, E., \& Ngumba, W. (2009), Guidance and counseling for schools and colleges. Nairobi: Oxford University Press.

Owino, A. (2005), 'An inquiry into the existence, establishment and programme delivery of Guidance and Counselling units in secondary schools in Uashin Gishu District, Kenya'. Unpublished M.Phil. Thesis, Moi University, Eldoret, Kenya.

Payne, E., \& Whitaker, L. (2006), Developing essential study skills ( $\left.2^{\text {nd }} \mathrm{ed}\right)$. New Jersey: Pearson Education.

Psacharopaulos, G., \& Woodhall, M. (2010), Education and Development: An Analysis of Investiment Choices. New York. Oxford University Press.

Sima, F. (2004), 'An Investigation of the Probable Causes of Poor Performance in K.C.S.E. in Matuga Division, Kwale District, Coast Province, Kenya’ Unpublished M.Ed Project, Kenyatta University.

Singh, T. K. (2014), 'Health and Adjustment of High School Students', International Journal of Indian Psychology, $1(4), 9-18$.

Sweetnam, K. R. (2012), Test taking strategies and student achievement. Minnesota: Running Head.

Taylor, H. (2012), School Guidance and Counselling. London: Macmillan.

Wango, G. M. (2007), 'Policy and Practice in Guidance and Counselling in Secondary Schools in Kenya' Unpublished PhD Thesis. The University of Birmingham, United Kingdom.

Wanjama, S. Muraya, P., \& Gichaka, T. (2006), 'An investigation of the Eextent of Guidance and Counselling Programmes in some Secondary Schools of Thika District, Kenya' Unpublished Thesis, Kenyatta University. 